\title{
THE MILITARY AND HUMANITARIAN ACTION
}

\author{
John H. King \\ Adjunct Professor, Webster University
}

One of the most interesting concepts to arise in the wake of the Cold War's demise is the use of military organizations in the conduct of humanitarian actions. The concept has created rising expectations that humanitarian crises will be met more effectively since military forces - when compared to other organizations - are in general better equipped, more disciplined and have greater resources to move into crisis areas, restore order and to get relief efforts started.

But, this new practice has created a number of urgent questions: Is this a workable concept for the $21^{\text {st }}$ century? What roles can the military play in humanitarian action? What are the limits on these roles? How does military action in the humanitarian field relate to international law? All of these questions are valid, and as we shall see, the answers are by no means clear. Nevertheless, the advantageous possibilities inherent in the concept make it essential to find workable answers.

First, given the apparent contradiction between the words "military" and "humanitarian," we need to look at what kind of military forces engage in humanitarian action. For the most part, they are forces that are under the control of civilian governments that are responsible to their populations. They can be military forces that undertake humanitarian actions in a national capacity (such as the U.S. in Haiti) or in an international capacity (such as the UN-established task forces). But in general, they are armed forces that are ultimately governed by the rule of law as asserted through responsible governments.

The distinction is important, since no one thinks of humanitarian action in connection with, for example, the Yugoslav Federal army or the Iraqi Republican Guard. Since international law concerning the military and humanitarian action is still evolving, it is essential that those military forces that engage in humanitarian action do so with a sensitive regard for new ground they are breaking. Only those forces controlled by civil governments attuned to such sensitivities can credibly undertake such actions. Otherwise, military action in the humanitarian field could be - and sometimes has been - criticized as disguised military intervention in the pursuit of political gain.

The post Cold War period has seen the rise of military interventions for humanitarian reasons precisely because civilian populations have pressured their governments for such action. Those governments have had to react to the pressure even though it meant using their armed forces for untraditional purposes. In this regard, the first objective of any armed force is the defense of the nation-state from which it arises, followed by a 
second objective of projecting the power of the nation-state outside its borders as deemed appropriate. Armed forces are organized to achieve those objectives. Adding the new objective of intervening for humanitarian action purposes has created significant turmoil in the management practices of armed forces, especially where humanitarian operations must be conducted in tandem with the forces of other nations. The concept also involves coordination with humanitarian aid agencies, NGOs and other organizations with which the military has had scant contact, and with whom they are only beginning to learn to work effectively. Trial-and-error has been the primary (and painful) learning process.

Nevertheless, those military establishments that have been asked to undertake such humanitarian action roles have responded well, as their governments knew they would. The sense of discipline and urgency that characterizes most military forces has brought about reorganization and redirection of those military elements assigned to humanitarian tasks. The newness of the humanitarian action role and the uncertainty created by its still-developing legal underpinnings have created some hesitations and missteps, but in general military forces so engaged are showing remarkable adaptability. As long as the humanitarian action concerned has the political approval of the civilian population supporting the force, the military will apparently do what is necessary, within existing legal, logistical and political constraints, to achieve their new objective.

And what is that objective? Actually, there are several that have developed over the past several years, based mostly on trial-and-error practice.

First, since military forces have come to be the first organizational elements to intervene in developing humanitarian crisis areas, at least where those crises are created by hostile military action of one kind or another, the intervening military are required to use force to stop or reduce the humanitarian problems created by such hostile action. No other organized element can do that, and it is the primary aim of using the military in areas where humanitarian action is needed. The end of the military standoff of the cold war has made this type of intervention possible, and the need for it paradoxically has blossomed as the military restraints of the cold war were removed. In this regard, military intervention in humanitarian crises is the first and crucial step that allows longer-term humanitarian action to be carried out by humanitarian organizations and other groups that do this work as their primary function, but are prevented from doing so by hostile military forces.

Flowing from this primary objective, military forces engaged in humanitarian action are often asked to undertake peace-making and then peacekeeping tasks. These functions allow humanitarian relief organizations to enter or re-enter a crisis area and do their work in relative safety. Essentially, the military take on a police function as their contribution to humanitarian action. But this is not and cannot be a permanent role, since military forces were not created for this purpose. 
Which leads to the next objective. Military forces intervening for humanitarian action purposes often use their expertise to train local forces and personnel in police and other security functions. They train local military forces to oppose the hostile forces provoking the crisis. They establish the basis for rudimentary governmental functions to be carried out but - and this is important - do not carry them out themselves except occasionally in an advisory capacity. Military forces engaged in humanitarian action are not and refuse to be "nation-builders". The Somalia experience cured that tendency by showing that military intervenors simply do not have the political will or expertise to carry out such a complicated, long-term task.

Military forces engaged in humanitarian action have another important role - to secure the return of refugees. Countries which send their forces into a crisis area for humanitarian purposes often have this goal in mind, if for no other reason than to take the pressure off themselves to accept and maintain such refugees. Cynicism aside, this role is important, since the returned refugees constitute the local manpower base to take on the longer-term reconstruction and development tasks for which the humanitarian aid organizations are presumably preparing the way.

Because of the continuing political pressure for military establishments to undertake humanitarian action, and because these forces appear to be undertaking such a non-traditional military role with increasing success, the concept appears to be a workable one. However, many problems in the use of military forces for such purposes have become apparent, and the concept has clear limitations.

In discussing these limitations in a 1995 speech, the then U.S. Chairman of the Joint Chiefs of Staff, General Shalikashvili, referred to an old Confucian saying that "when you save a person's life, you are responsible for that person for the rest of their life." After observing the downsides of that saying for people who want to become doctors, he noted that in helping other nations, there are limits to the help that can be offered. He concluded that the scope of the help offered has to reflect the national interests of the state offering the help, or the effort will not be sustained by popular support. In other words, he was saying that the political pressure to use the military in humanitarian action has its limits, and that those limits are political rather than humanitarian. The lesson here is that the use of the military for humanitarian action may initially spring from well-intentioned humanitarian motives, but its underlying and long run motivation is essentially political. There should be no surprise in this, although it is a disappointing fact of life to those of us with a humanitarian disposition.

Another limitation, pointed out in a 1995 speech by former U.S. Secretary of Defense William Perry, is that planning for the use of military force for ethical humanitarian purposes has to involve a calculation of the risks involved, especially for the loss of soldiers' lives. When the security of a nation is not involved in a military action, the simple political fact is that the nation's civilian population, while desiring humanitarian inter- 
vention, will quickly lose that desire when the casualties mount. They consider, not unrealistically, that the purpose of the action is to save lives, not to lose them. Therefore, such interventions have to be carefully planned, with exit strategies and alternatives always in mind. In essence, planning for the use of military force for humanitarian purposes has to be a finely balanced exercise - enough to meet the basic objectives of the intervention without running unacceptable risks. Those of you who have seen the recent movie, "Blackhawk Down", about the failure of the U.S. humanitarian intervention in Somalia know what I am talking about.

This limitation can be somewhat attenuated if the humanitarian intervention is carried out in conjunction with the military forces of other nations. In such situations, the risk - both real and political - is shared, and therefore better tolerated by the civilian populations supporting the forces. This strategy works in some areas (e.g. the Balkans) but not in others (e.g. Afghanistan) since only the U.S. currently has the military capability to project force over long distances into remote areas. Most assistance rendered by non-U.S. countries is perforce limited to those areas to which they have ready access.

The use of military forces for humanitarian action under the UN banner is one way to attempt to overcome these limitations. UN forces, however, have their own limitations: the forces involved are usually small and relatively ineffective; they are improperly trained for their tasks and unable to work together easily because of differing military doctrines, command structures and communications problems; and they are subject to constant mission revision by the UN Security Council. Some humanitarian crises cannot be met at all by the UN due to Security Council disputes (e.g., Kosovo).

The use of NATO forces for humanitarian purposes has overcome some of these problems since its integrated command structure allows for the more efficient use of multinational forces. However, NATO is often beset by political disputes of its own, and unlike the UN, has to take decisions based on consensus. Therefore, mission definition has been a serious problem for NATO in using its forces for humanitarian purposes. Furthermore, unlike the UN, NATO does not have the political standing to legitimize humanitarian action under international law, thus making its actions, although taken with humanitarian intentions, vulnerable to international criticism.

In the end, perhaps the most humanitarian use of military force is to prevent the outbreak of hostilities that create humanitarian disasters. As General Shalikashvili has pointed out, the deterrent role of NATO and other such organizations is perhaps even more relevant in this regard and should not be underestimated or underutilized. The concept of deterrence should therefore be rethought in order to make it more effective as a humanitarian tool, one which creates the stability required for disputes to be resolved peacefully as well as one which is used militarily and politically to stop humanitarian crises before they start. 
As the $21^{\text {st }}$ century begins, there appears to be little doubt that military involvement in humanitarian action is a politically viable concept. The concept will undoubtedly grow as the capacity of military forces to engage in such action increases, and they learn to do so with decreasing risk of loss of life. The concept is also increasingly supported by international law, although the process of constructing the legal framework to legitimize such actions is necessarily a slow and deliberate process in view of the need to garner widespread and consistent acceptance. At this point in time, therefore, international law mostly follows the military in humanitarian action, not the reverse.

In sum, the current limitations on the concept of using the military for humanitarian action are real and need to be resolved, but efforts to do so continue and must continue with increasing urgency. There is no better alternative in view. 